\title{
Influence of structural habitat use on the thermal ecology of Gonatodes humeralis (Squamata: Gekkonidae) from a transitional forest in Maranhão, Brazil
}

\author{
Jivanildo P. Miranda1, 4; Andréa Ricci-Lobão² \& Carlos Frederico D. Rocha ${ }^{3}$ \\ 1 Pós-Graduação em Ecologia, Instituto de Biologia, Universidade Estadual de Campinas. Caixa Postal 6109, \\ 13084-971 Campinas, São Paulo, Brasil. E-mail: jivanildo@ufma.br \\ 2 Departamento de Ciências Biológicas, Centro Universitário do Maranhão. Rua Josué Montello, 1, Renascença, \\ 65075-120 São Luís, Maranhão, Brasil. E-mail: andiemailbr@yahoo.com.br \\ ${ }^{3}$ Departamento de Ecologia, Instituto de Biologia, Universidade do Estado do Rio de Janeiro. Rua São Francisco Xavier 524, \\ Maracanã, 20550-011 Rio de Janeiro, Rio de Janeiro, Brasil.E-mail: cfdrocha@uerj.br \\ ${ }^{4}$ Corresponding author.
}

\begin{abstract}
We studied the structural habitat use and the thermal ecology of Gonatodes humeralis (Guichenot, 1855) in São Luís, Maranhão, Brazil, to examine intersexual differences in the use of perch features and to simultaneously analyze reciprocal differences on thermal ecology between the sexes. Gonatodes humeralis body temperature was strongly correlated with environmental temperatures (air and substrate), but air temperature had an additional effect on the males' body temperatures after removing the effect of the substrate temperature. Males and females differed significantly in perch height use above ground (males perched higher) but the sexes did not differ in the trunk perimeter used. Gonatodes humeralis tended to use the larger tree trunks available in its environment and selected trunks with deeper leaf litter at the base. It is hypothesized that choosing tree trunks with deeper leaf litter is a defensive behavior against predation.
\end{abstract}

KEY WORDS. Gecko; temperature; intersexual differences; microhabitat; thermoregulation.

The occurrence of a species at given site is correlated with specific environmental characteristics, such as food and shelter availability or microclimatic conditions, suggesting that these variables play an important role in the distribution and abundance of living organisms (SCHLESINGER \& SHINe 1994, WiLliams \& Mcbrayer 2007, Carvalho Jr et al. 2008). Lizards, as other ectotherms, are heavily influenced by habitat temperature, which may impose constraints that are of particular significance to small species because of their limited thermal inertia (STEvenson 1985). Small lizards, for example, need to continuously search for thermally suitable microhabitats, which can be energetically expensive (Huey \& S LATKIN 1976). Arboreal lizards are able to switch among different thermal environments only by changing their perch height, but in doing so they may also put themselves in less advantageous situations such as increased risk of predation, increased competition or less opportunities for reproductive interactions (Schoener \& Gorman 1968, Saenz 1996).

The choice of perch dimensions by arboreal lizards may affect both their visual field and exposure to predators, in opposite ways (Sсотт JR et al. 1976). For instance, a tree that has a wide diameter will reduce the lizards' visual field, while at the same time decreasing its exposure to visually oriented predators. As a result, the selection of perch diameter needs to balance food search and predator avoidance (Sсотт JR. et al. 1976). In addition to food search and predator avoidance, perch diameter also affects locomotory performance in arboreal lizards. Losos \& Irschick (1996) found a direct relationship between perch diameter and lizard sprint capacity. In a contribution that combines experimental with field data, Irschick \& Losos (1999) showed that species whose sprint capacity is highly affected by a reduction in perch diameter tend avoid perches on which their maximal sprinting abilities are impaired, whereas species less sensitive to a reduction in perch diameter may use trunks with a variety of diameters. Consistent with these results is the hypothesis that a lizard's sprint ability on the trunk plays an important role in determining perch diameter use. Therefore, the study of the structural habitat, represented by the distribution of perch heights and diameters used by undisturbed individuals under natural conditions (RAND 1964), simultaneously with thermal ecology, can be important in understanding the strategies and trade-offs driving the behavior and choices related to essential aspects of the ecology of many lizard species. 
Gonatodes humeralis (Guichenot, 1855) is a small and arboreal species found throughout most of the Amazonian region (Ávila-Pires 1995). In the present study, we examined the thermal ecology simultaneously with structural habitat use in a population of that diurnal gecko. We have addressed the following questions: (1) What is the activity body temperature of G. humeralis? (2) How dramatically do the temperatures of the air and substrate (environmental temperatures) influence the body temperature of G. humeralis? (3) Do males and females of G. humeralis differ significantly in body temperature? (4) Do environmental temperatures (air and substrate) differ at perch sites used by males and females of G. humeralis? (5) Are individuals of $G$. humeralis selective in regards to trunk perimeter? (6) Is the depth of the leaf litter at the base of the trunk (a potential retreat) important for the selection of a given perch by G. humeralis?

\section{MATERIAL AND METHODS}

This study was undertaken in a fragment of approximately 3,200 ha of a transitional forest area in the eastern Brazilian Amazon, São Luís, state of Maranhão, Brazil $\left(02^{\circ} 42^{\prime}\right.$ $\left.50,1^{\prime \prime} \mathrm{S}, 44^{\circ} 16^{\prime} 55,3^{\prime \prime} \mathrm{W}\right)$. We recorded G. humeralis in two abandoned paths of about $1.5 \mathrm{~km}$ length in the center of the fragment. The local climate is characterized by a distinct wet season from January to June (rainfall: higher than 2,000 mm/year) and by high temperatures (annual average ca. $28^{\circ} \mathrm{C}$ ) during the year (ARAújo et al. 1973).

We sampled individuals of $G$. humeralis between 7:00 am and 5:00 pm from March 4 to April 5, 2003 (total capture effort $=500$ person-hours). Specimens were hand-captured and had their body temperatures measured within $20 \mathrm{~s}$, using Schultheis quick-reading cloacal thermometers (to the nearest $0.2^{\circ} \mathrm{C}$ ). For each individual sampled we also recorded air (measured ca. 1 $\mathrm{cm}$ above the substrate where the lizard was originally perched) and substrate temperatures (taken directly on the lizard's perch substrate). Additionally, snout-vent length (SVL) was measured using calipers (to the nearest $0.1 \mathrm{~mm}$ ) and body mass was recorded using Pesola ${ }^{\circledR}$ spring scales (to the nearest $0.1 \mathrm{~g}$ ).

We investigated the relationship between lizard body temperatures and the thermal environment (air and substrate temperatures) using regression analyses and examined the additional effects of both environmental heat sources (air and substrate) on lizard body temperature using multiple regression analyses (ZAR 1999). We analyzed intersexual differences in the mean body temperature of active lizards using Student's t-test (ZAR 1999).

For each trunk used by $G$. humeralis we measured the following: 1) perch height above the ground; 2) perimeter of the perching trunk (measured both at the height where the lizard was originally sighted and at $30 \mathrm{~cm}$ above the ground); and 3) the depth of the leaf litter in four equidistant points (10 $\mathrm{cm}$ from the base of the perching trunk) around the trunk and at the same bearing. A measuring tape (to the nearest $1 \mathrm{~cm}$ ) and vernier calipers (to the nearest $0.1 \mathrm{~mm}$ ) were used to record tree trunk variables and the depth of leaf litter, respectively.

We compared the diameter of each perch with the diameters of the available trunks in the surroundings after establishing plots $(2 \times 2 \mathrm{~m})$ around the trunk used by the lizard. In addition, we measured the perimeter of the trunk (at $30 \mathrm{~cm}$ above the ground) and the same variables measured for perches in for all surrounding plants taller than $60 \mathrm{~cm}$.

The depth of leaf litter at the base of each perching trunk and at the base of the nearest neighboring tree were compared using the Wilcoxon paired-sample test (Siegel \& Castellan JR 1988). Intersexual differences in perch height and trunk perimeter were analyzed using the Student t-test (ZAR 1999). The correlation between the perimeters of the trunks used by lizards as perch and the perimeters (30 $\mathrm{cm}$ above the ground) of the other available plants was examined using Spearman's rank correlation (Siegel \& CASTELLAN JR 1988). The relationship between lizard SVL and either perch height or perch perimeter were analyzed using Pearson's correlation (ZAR 1999). The difference in lizard SVL and mass between sexes was examined using the Student t-test and the Mann-Whitney test (Siegel \& CAstellan Jr 1988, ZAr 1999), respectively. When assumptions of parametric tests could not be initially met, the data were transformed or correspondent non-parametric tests were performed. Means appear \pm 1 SD.

\section{RESULTS}

Intersexual SVL of $G$. humeralis differed significantly (males: $33.8 \pm 2.5 \mathrm{~mm}, \mathrm{n}=33$; females: $32.5 \pm 2.6 \mathrm{~mm}, \mathrm{n}=40$; $\mathrm{t}$ $=-2.1, \mathrm{df}=71, \mathrm{p}=0.04)$ and the same was observed for mass (males: median $=1.0 \mathrm{~g}$, range $=0.7-1.8 \mathrm{~g}$; females: median $=0.9 \mathrm{~g}$, range 0.6-1.3 g; Mann-Whitney, $\mathrm{U}=377, \mathrm{p}=0.03$ ).

We recorded temperatures (body, substrate and air) and data on habitat structure for 73 individuals (40 females, 33 males) of $G$. humeralis. The mean temperature of active males was $29.2 \pm 0.8^{\circ} \mathrm{C}\left(\right.$ range $=27.6-30.8^{\circ} \mathrm{C}$ ) and $28.9 \pm 0.9^{\circ} \mathrm{C}$ (range $=27.4-31.2^{\circ} \mathrm{C}$ ) for females. Intersexual mean body temperature did not differ significantly $(\mathrm{t}=-1.21$, $\mathrm{df}=71, \mathrm{p}=0.23$ ). Considering both sexes together, the mean activity temperature was $29.0 \pm 0.9^{\circ} \mathrm{C}$. Mean air temperature on the perching sites used by males was $28.0 \pm 0.9^{\circ} \mathrm{C}\left(\right.$ range $\left.=26.0-29.4^{\circ} \mathrm{C}\right)$ and on those used by females was $27.7 \pm 0.8^{\circ} \mathrm{C}\left(\right.$ range $\left.=25.8-29.4^{\circ} \mathrm{C}\right)$. Mean substrate temperature on the perches used by males was $27.6 \pm 0.9^{\circ} \mathrm{C}$ (range $=25.4-29.8^{\circ} \mathrm{C}$ ), whereas on those used by females was $27.2 \pm 0.9^{\circ} \mathrm{C}$ (range $=24.8-29.2^{\circ} \mathrm{C}$ ). Neither air nor substrate temperatures differed significantly between perching sites used by males or females $(\mathrm{t}=-1.41, \mathrm{df}=71, \mathrm{p}=0.16$ and $\mathrm{t}=-1.86, \mathrm{df}=71, \mathrm{p}=0.07$, respectively).

Body temperature of $G$. humeralis was positively and significantly correlated to both air and substrate temperatures (Figs 1 and 2). However, air temperature had an additional effect on the males' body temperatures when we removed the effect of substrate temperature (Multiple regression, $\mathrm{r}=0.75, \mathrm{~F}_{2,30}=19.18$, 

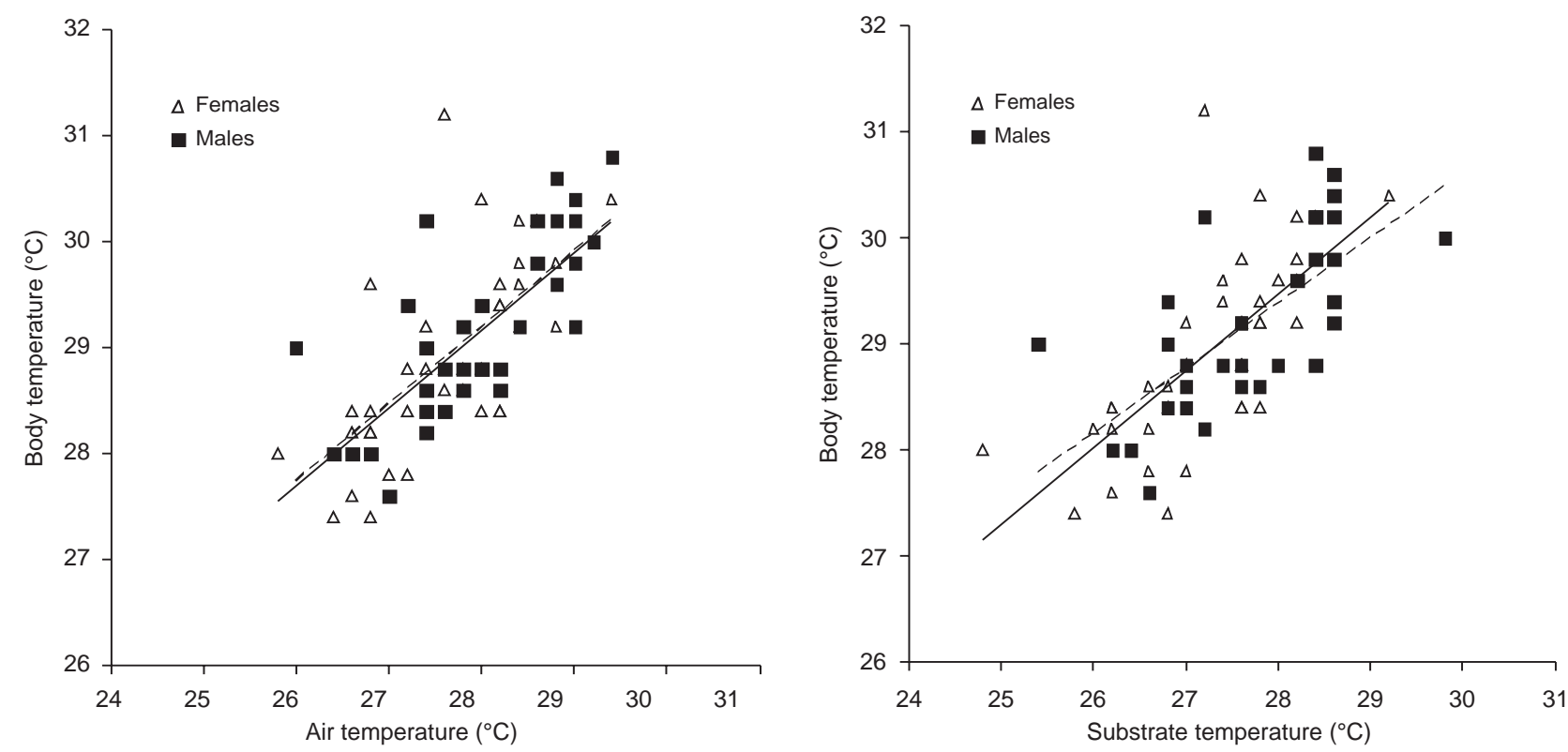

Figures 1-2. Relationships between air and body temperatures (1) and between substrate and body temperatures (2) of G. humeralis males and females. The dashed line represents the regression line for males (air vs. body, $y=0.73 x+8.86, R^{2}=0.56, p<0.001$; substrate vs. body, $y=0.61 x+12.2, R^{2}=0.48, p<0.001$ ) and the solid line represents the regression line for females (air vs. body, $y=0.73 x+8.61, R^{2}=0.46, p<0.001 ;$ substrate vs. body, $\left.y=0.68 x+7.6, R^{2}=0.49, p<0.001\right)$.

$\mathrm{p}<0.001 ; \mathrm{p}_{\text {air }}=0.02$ e $\left.\mathrm{p}_{\text {substrate }}=0.84\right)$. For females, however, neither air nor substrate temperatures had an additional effect on body temperature after factoring out the effect of the other heat source (Multiple regression, $\mathrm{r}=0.71, \mathrm{~F}_{2,37}=18.56, \mathrm{p}<0.001$; $\mathrm{p}_{\text {air }}=0.46$ e $\mathrm{p}_{\text {substrate }}=0.08$ ).

Mean perch perimeter did not differ between sexes $(t=$ $0.28, \mathrm{df}=70, \mathrm{p}=0.78-$ data $\log _{10}-$ transformed). Mean perch height of males was $47.5 \pm 28.6 \mathrm{~cm}(\mathrm{n}=33)$ and of females was $33.3 \pm 16.6 \mathrm{~cm}(\mathrm{n}=40)$. The sexes differed significantly in perch height use $\left(\mathrm{t}=2.32\right.$, df $=71, \mathrm{p}=0.023$ - data $\log _{10}-$ transformed). Mean perimeter (measured at $30 \mathrm{~cm}$ above the ground) of the tree trunks used by $G$. humeralis was $29.7 \pm 24.9 \mathrm{~cm}$ $(\mathrm{n}=72)$ and the mean perimeter of the tree trunks available in the surrounding area of the used tree trunk was $10.9 \pm 12.4 \mathrm{~cm}$ ( $n=544)$. We did not observe significant difference between the perimeter measured at $30 \mathrm{~cm}$ above the ground and at perch height on the same tree $(t=0.28, d f=142, p=0.78)$. There was no significant relationship between the perimeter of the tree trunks used by $G$. humeralis and the mean perimeter of the trees available around the lizard perch site (Spearman, $r_{s}=-0.012, p=0.92, n=72$ ). Lizard body size was not significantly correlated to either perch height or perimeter $(r=0.21$, $\mathrm{t}=1.8 \mathrm{p}=0.08 ; \mathrm{r}=0.02, \mathrm{t}=0.15, \mathrm{p}=0.88$ ) of the perch used.

The depth of the leaf litter at the base of trunks used by $G$. humeralis as perch did not differ between sexes (MannWhitney, $U=506 ; p=0.22$ ). However, leaf litter was deeper at the base of the perching trunks than at the base of the nearest neighboring tree (perching trunk: median $=41.4 \mathrm{~mm}$, range $=$ 0-109.5 mm; nearest neighbour: median $=39.7 \mathrm{~mm}$, range $=$ 4.2-109.5 mm; Wilcoxon, $\mathrm{T}=641, \mathrm{p}=0.002$ ). The mean distance from the perching trunks to their nearest neighbor trees was $33.5 \pm 24.5 \mathrm{~cm}(\mathrm{n}=67)$.

The density of trunks in the plots around the perching trunk used by G. humeralis did not differ between the sexes (males: median $=7$ trunks, range $=1-24$ trunks; females: median $=7$ trunks, range = 0-15 trunks; Mann-Whitney, $\mathrm{U}=578.5, \mathrm{p}=0.37$ ).

\section{DISCUSSION}

Consistent with predictions for small lizards living in shaded forests, where the costs of a careful thermoregulation may be too high (Huey \& SLATKIN 1976), our results have shown that, in almost every case, the body temperature of $G$. humeralis was similar to the environmental temperature. Mean activity temperature for this species, in our data, was consistent with temperatures previously reported for the species elsewhere: 28.4 $\pm 0.2^{\circ} \mathrm{C}$ ( $\mathrm{n}=24$; combined data of four localities, VitT et al. 1997) and $30.3 \pm 0.2^{\circ} \mathrm{C}(\mathrm{n}=47)$ in Guajará-Mirim State Park, Rondônia State, Brazil (VITT et al. 2000). Mean activity temperatures recorded for at least one congeneric species, Gonatodes hasemani Griffin, $1917\left(30.6 \pm 0.3^{\circ} \mathrm{C}, \mathrm{n}=22\right)$ in Guajará-Mirim State Park, Rondônia, Brazil (VITT et al. 2000) were also similar to our findings for $G$. humeralis.

In the present study, both environmental temperatures (air and substrate) explained the body temperatures recorded 
for $G$. humeralis when active $\left(\mathrm{R}^{2} \cong 0.50\right)$. Nevertheless, the relative contribution of each environmental temperature was different for each sex (the male's body temperature was more strongly influenced by the temperature of the air when compared with the females). This result could be at least in part explained by the fact that males used higher perches relative to females, which determines different microclimatic conditions for both sexes. In Manaus, Central Amazonia, G. humeralis used tree trunks with a mean perimeter (measured at $30 \mathrm{~cm}$ above the ground) of $94.2 \mathrm{~cm}$ and avoided trees with perimeters smaller than $21 \mathrm{~cm}$ (NunEs 1984). By contrast, VitT et al. (1997) and ViтT et al. (2000) reported average perch perimeters used by G. humeralis (measured at perch height) of $60.6 \mathrm{~cm}$ and $60.0 \mathrm{~cm}$, respectively. In this study, the tree trunks used by G. humeralis were comparatively thinner (i.e. had smaller diameter), stressing the plasticity of this species in the use of perching trunks. This result may be linked to the small body size of $G$. humeralis, which allows that lizard to hide even on thin trunks. Moreover, G. humeralis has digits with adhesive pads that may improve its locomotor capability and allow the use of trunks of many different diameters.

In Panamá, the occurrence of Gonatodes albogularis Duméril \& Bibron, 1836 was positively correlated with the density of trees having diameters larger than $40 \mathrm{~cm}$ at breast height (Heatwole \& Sexton 1966). In our study, G. humeralis individuals selected the largest tree trunks available to them, which were still thinner than those used by G. albogularis in Panamá. Individuals of $G$. humeralis, when disturbed, tend to move to the opposite side of the trunk, often running down to the leaf litter (pers. obs.). The use of trunks with deep leaf litter at the base may represent a defensive strategy to escape from predators that complements the use of larger tree trunks. This strategy, however, is not expected to be equally effective for males and females, because males perch higher and cannot retreat to the bottom of the trunk as quickly as females can.

Intraspecific differences in perch height observed in our study may be explained by at least two non-exclusive hypotheses. First, it may result from differences in male behavior during the reproductive season. Miranda \& ANDRADE (2003) studied perch height use by $G$. humeralis during the rainy and dry seasons and found that males perched higher than females only during the rainy season, which corresponds to the reproductive season. They suggested that, by using higher perches, males can better defend their territories and thus improve their chances of finding mates. Second, it may result from the correlation between lizard morphology and structural habitat features. If there is sexual dimorphism in size, the match between lizard and perch may reduce intraspecific competition by habitat partitioning (Collette 1961, Schoener 1968, Williams 1983, Losos 1990). However, the sexual dimorphism in size observed for $G$. humeralis in this study was less pronounced than that observed for Anolis species, from which habitat partitioning related to the match between lizard size and perch diameter has been repeatedly reported (SCHOEnER 1968, SCHOENER \& GoRman 1968, Huey et al. 1983). Moreover, many studies have demonstrated that in areas with marked rainfall seasonality, arthropods are more abundant during the rainy season (e.g., BaLlinger \& Ballinger 1979, Griffiths \& Christian 1996) which may reflect a higher abundance of resources. In such cases, the highest level of intraspecific competition in lizards (if present) is expected to happen during dry season (due to resource limitation). However, the sexual difference in perch height observed in $G$. humeralis occurs only in the rainy season (Miranda \& ANDRADE 2003), strengthening the hypothesis that perch height differences observed for $G$. humeralis are best explained by pressures linked to reproduction rather than intraspecific competition. Additionally, because the higher perch used by males during the rainy (and reproductive) season affects thermoregulation (if a lizard chooses a thermally improper microhabitat, then it will face reduced physiological performance, which would reduce its overall fitness) and also decreases the opportunities to reach retreats on the leaf litter, males of $G$. humeralis would be exposed to the costs related to that perch choice.

Some questions remain that have not been answered by this research, for example; why do males perch higher than females during the reproductive season? What are the potential benefits of this behavior? In future studies, it would be interesting to assess if perch choice in Gonatodes humeralis is connected to sexual selection. In this case, the higher perch selected by $G$. humeralis males could acts as a handicap signal to potential mates.

\section{ACKNOWLEDGMENTS}

We are grateful to Monique Van Sluys, Otávio Marques, Eleonore Setz, and Keith Brown Jr for useful comments on earlier drafts; to Kleber Del Claro and anonymous reviewers for valuable suggestions on the manuscript, to Francisco Cavalcante for help in the field and to Leena Ronkainen for English review on the manuscript. We also thank IDEAWILD for grants provided to JPM; ALUMAR S.A. for permits to access the study area. JPM was supported by Coordenação de Aperfeiçoamento de Pessoal de Nível Superior (CAPES) and CFDR by Conselho Nacional do Desenvolvimento Científico e Tecnológico (CNPq).

\section{LITERATURE CITED}

Araújo, J.V.; L.S. Vieira; M.P. Araújo \& J. S. Martins. 1973. Solos, p. 34-47. In: Projeto Radam. Rio de Janeiro, Departamento Nacional de Produção Mineral, vol. 3, 331p.

Ávila-PiRes, T.C.S. 1995. Lizards of Brazilian Amazonia (Reptilia: Squamata). Zoologische Verhandelingen 299 (1):1-704.

BALlinger, R.E. \& R.A. BALLinger. 1979. Food resource utilization during periods of low and high food availability in Sceloporus jarrovi (Sauria: Iguanidae). Southwestern Naturalist 24 (2): 347-363.

Carvalho Jr, E.A.R.; A.P. Lima; W.E. Magnusson \& A.L.K.A. Albernaz. 2008. Long-term effect of forest fragmentation on 
the Amazonian gekkonid lizards, Coleodactylus amazonicus and Gonatodes humeralis. Austral Ecology 33 (6): 723-729.

Collette, B.B. 1961. Correlations between ecology and morphology in anoline lizards from Havana, Cuba and Southern Florida. Bulletin of the Museum of Comparative Zoology 125 (5): 137-162.

Griffiths, A.D. \& K.A. Christian. 1996. Diet and habitat use of frillneck lizard in a seasonal tropical environment. Oecologia 106 (1): 39-48.

Heatwole, H. \& O.J. Sexton. 1966. Herpetofaunal comparisons between two climatic zones in Panama. American Midland Naturalist 75 (1): 45-60.

Huey, R.B.; E.R. Pianka \& T.W. Schoener (Eds). 1983. Lizard Ecology: studies of a model organism. Cambridge, Harvard University Press, 501p.

Huey, R.B. \& M. Slatkin. 1976. Costs and benefits of lizard thermoregulation. Quarterly Review of Biology 51 (3): 353384.

IRSCHICK, D.J. \& J.B. Losos. 1999. Do lizards avoid habitats in which performance is submaximal? The relationship between sprinting capabilities and structural habitat use in Caribbean Anoles. American Naturalist 154 (3): 293-305.

Losos, J.B. 1990. The evolution of form and function: morphology and locomotor performance in West Indian Anolis lizards. Evolution 44 (5): 1189-1203

Losos, J.B. \& D.J. Irschick. 1996. The effect of perch diameter on escape behaviour of Anolis lizards: Laboratory predictions and field tests. Animal Behaviour 51 (3): 593-602.

Miranda, J.P. \& G.V. Andrade. 2003. Seasonality in diet, perch use and, reproduction of the gecko Gonatodes humeralis from eastern Brazilian Amazon. Journal of Herpetology 37 (2): 433-438.

Nunes, V.S. 1984. Ciclo de atividade e utilização do habitat por Gonatodes humeralis (Sauria, Gekkonidae) em Manaus, Amazonas. Papéis Avulsos de Zoologia 35 (13): 147-152.

RAND, S.A.1964. Ecological distribution in anoline lizards of Puerto Rico. Ecology 45 (4): 745-752.

SAENZ, D. 1996. Dietary overview of Hemidactylus turcicus with possible implications of food partitioning. Journal of Herpetology 30 (4): 461-466.

Schlesinger, C.A. \& R. Shine. 1994 Selection of diurnal retreat sites by the nocturnal gekkonid lizard Oedura lesueurii. Herpetologica 50 (2): 156-163.

Schoener, T.W. 1968. The Anolis lizards of Bimini: resource partitioning in a complex fauna. Ecology 49 (4): 704-726.

Schoener, T.W. \& C.G. Gorman. 1968. Some niche differences in three lesser Antillean lizards of the genus Anolis. Ecology 49 (5): 819-830.

ScotT JR, N.J.; D.E. WiLson \& R.M. AndREws. 1976. The choice of perch dimensions by lizards of the genus Anolis (Reptilia, Lacertilia, Iguanidae). Journal of Herpetology 10 (2): 75-84.

Siegel, S. \& N. J. Castellan JR. 1988. Nonparametric Statistics for the Behavioral Sciences. New York, McGraw-Hill, $2^{\text {nd }}$ ed., 399p.

STEVENSON, R.D. 1985. Body size and limits to the daily range of body temperature in terrestrial ectoterms. American Naturalist 125 (1): 102-117. doi: 10.1086/284330.

VitT, L.J.; P.A. ZANI \& A.M. BARRos 1997. Ecological variation among populations of the gekkonid lizard Gonatodes humeralis in the western Amazon Basin. Copeia 1997 (1): $32-43$.

VitT, L.J.; R.A. Souza; S.S. Sartorius; T.C.S. Avila-Pires \& M.C. Espósito. 2000. Comparative ecology of sympatric Gonatodes (Squamata: Gekkonidae) in western Amazon of Brazil. Copeia 2000 (1): 83-95.

Williams, E.E. 1983. Ecomorphs, faunas, island size, and diverse end points in island radiations of Anolis, p. 326-370. In: R.B. Huey; E.R. Pianka \& T.W. Schoener (Eds). Lizard Ecology: studies of a model organism. Cambridge, Harvard University Press, 501p.

Williams, S. \& L.D. McBrayer. 2007. Selection of microhabitat by the introduced Mediterranean gecko, Hemidactylus turcicus: influence of ambient light and distance to refuge. Southwestern Naturalist 52 (4): 578-585.

ZAR, J.H. 1999. Biostatistical Analysis. New Jersey, Prentice Hall, $4^{\text {th }}$ ed., 929p.

Submitted: 24.V.2009; Accepted: 19.I.2010.

Editorial responsibility: Kleber del Claro 